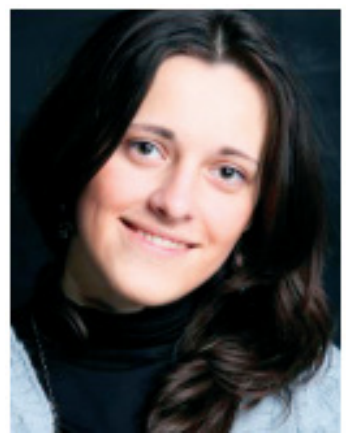

\author{
O. P. Fayura ${ }^{1}$, M. O. Abrahamovych ${ }^{1}$, \\ O. O. Abrahamovych ${ }^{1}$, L. R. Fayura ${ }^{2}$ \\ ${ }^{1}$ Danylo Halytsky Lviv National Medical University \\ ${ }^{2}$ Institute of Cell Biology of the National Academy \\ of Sciences of Ukraine
}

\title{
Redox Homeostasis Index as a Criterion for Differentiated Inclusion of Antioxidants to the Complex Treatment of Patients with Liver Cirrhosis of Different Severity and Evaluation of Its Effectiveness
}

Introduction. It is known that the features of occurrence, course and severity of the internal organs diseases are largely determined by the oxidative stress - the redox homeostasis imbalance with the prooxidants system prevalence, which realizes its pathogenetic mechanism through the endothelial dysfunction [1, 2, 6, 7]. Liver cirrhosis (LC) is not an exception. However, the enzymatic and non-enzymatic mechanisms of protection of the organism from the oxidative stress, which should create a kind of "shield" for the cells $[23,24]$ in the cirrhotic patients, are weakened [23]. Among the protective substances, there are vitamins, especially A, C, E, as well as microelements, including selenium $[11,14,31]$. But the reactive oxygen species (ROS) in the cirrhotic patients are not sufficiently neutralized with all the pathological consequences of this. Taking into account the important role of oxidative stress among the etiological and pathogenetic mechanisms of the occurrence and course of the disease, the pharmacological impact on it deserves priority in the complex treatment of the cirrhotic patients, requiring treating it as one of the main "targets".

The efficacy of the treatment of the cirrhotic patients largely determines the correctness of the redox homeostasis assessment, definition of the variant and severity of the pro- and antioxidants ratio disorders in it, allowing to include the necessary drugs to the treatment complex differentially.

The aim of the study. To characterize the redox homeostasis index (RHI) as a criterion for the differential inclusion of the antioxidants to the complex treatment of patients with liver cirrhosis of different severity and evaluation of its effectiveness.

Materials and methods. The study was conducted in three steps. With the preliminary stratification by the presence of LC (Order of the Ministry of Health (MOH) of Ukraine N 271 dated June 13, 2005 "On approval of Protocols for the Medical Care Provision on the Specialty "Gastroenterology") and in the accordance with the principles of the Declaration of Helsinki, Council of Europe Convention on Human Rights and Biomedicine, the relevant laws of Ukraine, 75 patients ( 23 women $(30.7 \%), 52$ men $(69.3 \%)$ of average age $-47.2 \pm 10.4$ years) were involved in the randomized study, for whom the complex clinical-laboratory-instrumental examination and inpatient treatment (sub-item 1.11, item 4 of the above-mentioned Order N 271 dated June 13, 2005) at Lviv Regional Hepatology Center, established on the basis of the Department of Internal Medicine N 1 of Danylo Halytsky Lviv National Medical University and the Gastroenterology Department of the Municipal Nonprofit Enterprise of Lviv Regional Council "Lviv Regional Clinical Hospital" after obtaining the written consent for the study.

LC of alcoholic genesis was identified in 50 patients $(66.7 \%)$, hepatitis $\mathrm{C}$ virus - in six patients $(8.0 \%)$. In $25.3 \%$ of cases (19 people), the mixed etiology of LC, namely combined, was diagnosed. It was impossible to identify the cause of LC in one patient (1.3\%).

The stratification of patients with LC, depending on its severity, was determined according to the criteria of C. H. Child - R. N. Pugh. 19 (25.3\%) patients (3 women $(33.3 \%), 16$ men $(84.2 \%)$ of average age $-43.8 \pm 9.9$ years) belonged to class A, $29(38.7 \%)$ patients ( 9 women $(31.0 \%), 20$ men $(69.0 \%)$ of average age $-45.6 \pm 9.4$ years) - class B, $27(36.0 \%$ ) patients (11 women $(40.7 \%)$, 16 men $(59.3 \%)$ of average age $-51.3 \pm 10.8$ years $)$ class $\mathrm{C}$.

The indices of redox homeostasis were determined by the content of malondialdehyde (MDA) and catalase 
(CAT). To determine the MDA content, we used a method based on the activation of lipid peroxidation by ferric ions $\left(\mathrm{Fe}^{2+}\right)$ (Sigma-Aldrich reagents, USA) to the amount that can be recorded spectrophotometrically. In the conditions of high temperature and acidic environment, MDA reacts with 2-thiobarbituric acid, forming a colored trimethyne complex with a maximum absorption peak of $532 \mathrm{~nm}$ [4]. To determine the content of CAT, we used a method based on the ability of hydrogen peroxide $\left(\mathrm{H}_{2} \mathrm{O}_{2}\right)$ to form a stable colored complex with molybdenum salts (SigmaAldrich reagents, USA). The color intensity of molybdenum peroxide compounds depends on the amount of $\mathrm{H}_{2} \mathrm{O}_{2}$ in solution, because CAT, decomposing $\mathrm{H}_{2} \mathrm{O}_{2}$, reduces the color intensity of the sample [3].

We proposed to calculate a comprehensive parameter of the pro- and antioxidants system status - RHI - the CAT to MDA contents ratio. Reduced RHI $(<7.6)$ was considered as the indicator of redox homeostasis abnormality with the prooxidant system predominance, value within 7.6-18.1 - balance in the redox homeostasis system, increased (>18.1) - indicator of the antioxidant system excessive activity.

The first step of our study was to determine the RHI to detect the disorders of redox homeostasis in patients with different LC severity degrees before the treatment, i.e. obtaining the information about the presence of patients with reduced, normal and increased values, which allows us to recommend the modification of standard complex treatment using antioxidants (medicine containing retinol palmitate (vitamin A) $100000 \mathrm{MO}$ and $\alpha$-tocopherol acetate (vitamin E) $0.1 \mathrm{~g}$ - 1 capsule per os once a day after meals daily, ascorbic acid $0.05 \mathrm{~g}-2$ tablets per os once a day after meals daily, selenium $0.0002 \mathrm{~g}-1$ tablet per os once a day after meals daily for two months) only for patients with reduced RHI.

The second step of the study was devoted to the determination of RHI after a course of complex differentiated treatment of the same patients with LC of varying severity.

The third step of the study was to compare the RHI obtained after the course of complex differentiated treatment of patients with LC varying severity degrees with the values of the RHI prior to treatment.

The actual material was processed on a personal computer in Excel 2010, Statistica 6.0, RStudio v. 1.1.442 and R Commander v. 2.4-4 using descriptive statistics. Each parameter was tested for normality of distribution. Student's (William Sealy Gossett's) t-test was used to compare the samples with normal distribution, three or more groups were compared by ANOVA (using J. Tukey's range test). The H. B. Mann - D. R. Whitney criterion was used to compare the samples with abnormal distribution. Comparison of three and more groups was provided using W. Kruskel - W. A. Wallis (using O. J. Dunn's test). The results obtained are presented in the form of Me $[25.0 \% ; 75.0 \%]$. The difference was considered statistically significant if $p<$ 0.05 .

Results and discussion. The results of the first step of the study devoted to the determination of RHI for the redox homeostasis disorders detection in patients with different LC severity degrees before the treatment made it possible to distinguish the patients with its reduced within the reference ranges and increased values, being described in table 1, and modify their standard complex treatment with antioxidant administration only for the patients with RHI $<7.6$.

Table 1

Redox homeostasis index in patients with liver cirrhosis of different severity degrees before the treatment $(n ; \% ;$ Me $(25.0 \% ; 75.0 \%) ; p)$

\begin{tabular}{|c|c|c|c|c|c|c|c|}
\hline \multirow{3}{*}{\multicolumn{2}{|c|}{$\begin{array}{l}\text { LC severity classes } \\
\text { according to the criteria } \\
\text { of } \\
\text { C. H. Child - R. N. Pugh }\end{array}$}} & \multicolumn{6}{|c|}{ RHI } \\
\hline & & \multicolumn{2}{|c|}{$<7.6$} & \multicolumn{2}{|c|}{$7.6-18.1$} & \multicolumn{2}{|c|}{$>18.1$} \\
\hline & & $n$ & $\%$ & $n$ & $\%$ & $n$ & $\%$ \\
\hline \multicolumn{2}{|l|}{ A; $n=19$} & 11 & 57.9 & 3 & 15.8 & 5 & 26.3 \\
\hline \multicolumn{2}{|c|}{$\operatorname{Me}(25.0 \% ; 75.0 \%)$} & \multicolumn{2}{|c|}{$3.3(1.7 ; 3.9)$} & \multicolumn{2}{|c|}{$\begin{array}{c}10.7(9.5 \\
12.9)\end{array}$} & \multicolumn{2}{|c|}{$\begin{array}{l}22.4(22.1 ; \\
24.0)\end{array}$} \\
\hline \multicolumn{2}{|l|}{$\mathrm{B} ; n=29$} & 28 & 96.6 & 1 & 3.4 & 0 & 0.0 \\
\hline \multicolumn{2}{|c|}{$\operatorname{Me}(25.0 \% ; 75.0 \%)$} & \multicolumn{2}{|c|}{$1.8(0.8 ; 3.9)$} & \multicolumn{2}{|c|}{14.0} & \multicolumn{2}{|c|}{ - } \\
\hline \multicolumn{2}{|l|}{$C ; n=27$} & 27 & 100.0 & 0 & 0.0 & 0 & 0.0 \\
\hline \multicolumn{2}{|c|}{$\operatorname{Me}(25.0 \% ; 75.0 \%)$} & \multicolumn{2}{|c|}{$0.8(0.5 ; 1.5)$} & \multicolumn{2}{|c|}{-} & \multicolumn{2}{|c|}{ - } \\
\hline \multicolumn{2}{|l|}{ Total $(n=75)$} & 66 & 88 & 4 & 5.3 & 5 & 6.7 \\
\hline \multicolumn{2}{|c|}{$\operatorname{Me}(25.0 \% ; 75.0 \%)$} & \multicolumn{2}{|c|}{$1.4(0.7 ; 3.5)$} & \multicolumn{2}{|c|}{$\begin{array}{c}12.4(10.1 ; \\
14.3)\end{array}$} & \multicolumn{2}{|c|}{$\begin{array}{c}22.4(22.1 ; \\
24.0)\end{array}$} \\
\hline \multirow{3}{*}{$\begin{array}{l}\text { Significance } \\
(\%), p\end{array}$} & AvsB & \multicolumn{2}{|c|}{0.02} & \multicolumn{2}{|c|}{$>0.05$} & \multicolumn{2}{|c|}{ - } \\
\hline & BvsC & \multicolumn{2}{|c|}{$>0.05$} & \multicolumn{2}{|c|}{ - } & \multicolumn{2}{|c|}{ - } \\
\hline & AvsC & \multicolumn{2}{|c|}{0.008} & \multicolumn{2}{|c|}{ - } & \multicolumn{2}{|c|}{ - } \\
\hline \multirow{3}{*}{$\begin{array}{l}\text { Significance } \\
(\mathrm{Me}(25.0 \% \text {; } \\
75.0 \%), p\end{array}$} & AvsB & \multicolumn{2}{|c|}{$>0.05$} & & & & \\
\hline & BvsC & & 006 & & & & \\
\hline & AvsC & & 007 & & & & \\
\hline
\end{tabular}

It was found that RHI less than the reference values was found in 66 cirrhotic patients $(88.0 \%$ of all 75 patients enrolled in the study), being $1.4(0.7 ; 3.5)$, and taking into account the severity criteria of C. G Child - R. N. Pugh - in 11 out of 19 $(57.9 \%)$ patients of class A $(3.3(1.7 ; 3.9))$, in 28 out of 29 $(96.6 \%)$ of class B $(1,8(0,8 ; 3,9))$, in 27 out of $27(100,0 \%)$ patients of class $\mathrm{C}(0,8(0,5 ; 1,5))$, with a significant difference between the frequencies in classes $\mathrm{A}$ and $\mathrm{B}(p=0.02), \mathrm{A}$ and $\mathrm{C}(p=0.008)$, and between the percentile values in classes $\mathrm{B}$ and $\mathrm{C}, \mathrm{A}$ and $\mathrm{C}(\mathrm{p}=0.0006 ; p=0.0007)$, that is, the incidence of RHI lower than the reference values increases, and its absolute value decreases in parallel with the LC severity increase. 
RHI within the reference values was detected in only four cirrhotic patients (5.3\% of all 75 patients enrolled in the study), being 12.4 (10.1; 14.3), and taking into account the severity criteria of C. G. Child - R. N. Pugh - in three $(15.8 \%)$ of 19 patients of class $A(10.7(9.5 ; 12.9))$, in one (3.4\%) of 29 patients of class B (14.0), and in none of class $\mathrm{C}$, that is, the incidence of RHI within the reference values tends to decrease with the LC severity increase.

RHI higher than the reference values was found only in five cirrhotic patients of class $\mathrm{A}(6.7 \%$ of all 75 patients enrolled in the study and $26.3 \%$ of all 19 patients of this class), being $22.4(22.1 ; 24.0)$, that may indicate a subclinical disorder of redox homeostasis with the antioxidant system enhanced activation in them.

The results obtained indicate that the overwhelming majority of the cirrhotic patients (71 persons, which is $94.7 \%$ of all involved in the study) have the redox homeostasis disorders, among which, the patients with the signs of prooxidant system prevalence and the impaired antioxidant system activity are predominant (66 persons, which is $88.0 \%$ of all 75 patients enrolled in the study), as well as the incidence of which significantly increases, and the value of RHI decreases with the LC severity increases.

Since the redox homeostasis disorders with the antioxidant system activity attenuation signs have been diagnosed in the overwhelming majority of the cirrhotic patients, determining the features, onset of the disease and the syntropic comorbid lesions severity increase, its medication adjustment is needed.

It should be noted that the liver is the main organ that stores $\alpha$-tocopherol [16] - the main liposoluble antioxidant in the body, which acts by disrupting the chain structure of compounds that occur in case of lipid peroxidation [12], inactivating peroxide radicals, that were synthesized, with the formation of tocopheroxyl radical. Tocopherol acts as a non-competitive inhibitor of cyclooxygenase, a suppressor of vascular endothelial growth factor and transforming growth factor $\beta[5]$, causes the tumor necrosis factor $\alpha$ synthesis decrease in patients with alcoholic hepatitis [18], as well as hepatic stellatae cells activation prevention in patients with chronic hepatitis C [20]. Oxidative stress in patients with liver damage causes the vitamin $\mathrm{E}$ secretion into the plasma decrease even before its content decreases in the liver [19, 25, 32], in particular, it concerns the patients who consume alcohol in large amounts, and vitamin $\mathrm{E}$ content negatively correlated with the consumed ethanol amount increase and the concentration of oxidized lipoperoxides. Thus, the plasma $\alpha$-tocopherol content decrease may also reflect the prooxidant effect of alcohol in the liver. M. Cankurtaran et al. [13] found a correlation between the decreased vitamin E content, increased triglyceride content, and sonographic findings in the liver, which are negative prognostic factors for the transformation of steatohepatitis to LC. The importance of the vitamin $\mathrm{E}$ antioxidant properties in the prevention of fibrosis was first proven in animal studies [34] and soon - clinically confirmed [17]. J. Kaur et al. [21] have shown that the use of vitamin E can restore redox status, prevent the oxidative stress occurrence, reduce apoptosis, and can be used as a promising tool in the comprehensive treatment of ethanol-induced liver disease [21]. It was found that the vitamin $E$ use contributed to the reduction of MDA content in serum and increase the content of serum nitric oxide, vitamin $\mathrm{C}$ and the activity of antioxidants - erythrocyte superoxide dismutase, CAT in patients undergoing hemodialysis [10, 15, 29, 33].

Ascorbic acid is the most potent intracellular and extracellular water-soluble antioxidant capable to absorb almost all physiologically important ROS by inactivating superoxide, hydroxyl anions and peroxide radical, hypochlorite and singlet oxygen [28]. Ascorbic acid is an important cofactor in enzymatic reactions that are involved in many biochemical processes, as an electron donor, being a free radical scavenger [26]. Vitamin C alone or in synergy with other substances reduces lipid peroxidation directly or indirectly through the regeneration of vitamin $\mathrm{E}$ [8]. It was found that the level of the vitamin $\mathrm{C}$ content in serum in case of alcoholic liver disease severity increases [19]. However, it has also been found that ascorbic acid in large doses induces pro-fibrotic effects $[27,29,32]$, becoming a pro-oxidant and causing iron-mediated damage of liver cells [9].

Therefore, vitamins $\mathrm{C}, \mathrm{E}$ have a synergistic antioxidant effect. However, vitamin $\mathrm{C}$ in cells can play both pro- and antioxidant roles, and the administration of large doses of ascorbate in patients with hypovitaminosis $E$ enhances the pro-oxidant effect of vitamin $\mathrm{C}$ twice. In turn, the pronounced antioxidant effect of vitamin $\mathrm{C}$ is found only in the case of its combination with $\alpha$-tocopherol, since the latter eliminates the free radicals formed in the reactions of ascorbate-stimulating lipid peroxidation. At the same time, vitamin $\mathrm{E}$ is rapidly destroyed in case of ascorbic acid insufficient amount. The antioxidant effect of $\alpha$-tocopherol is enhanced by the enough amount of vitamin A, which helps to eliminate ROS, preventing the occurrence of lipid peroxidation in biomembranes. However, vitamin A is easily oxidized by oxygen and consumed relatively quickly. This process is autocatalytic with the formation of free radicals. Vitamin E has a stabilizing effect on retinol and $\beta$-carotene, preventing their oxidative degradation. In other words, vitamin A dose increase, should be combined with taking tocopherol, and taking tocopherol with vitamin A administration. Also, vitamin $E$ should be used in combination with vitamin $\mathrm{C}$. Thus, the effectiveness of vitamins-antioxidants depends on the fact if they are used solitary or in combination with each other, at least because the vitamins $\mathrm{A}$ and $\mathrm{C}$ that are administered separately can cause a pro-oxidant effect on the body tissues.

Selenium is an important antioxidant-microelement in human organism. In recent years, the study of its content has aroused the great interest because of the important role of selenoprotein antioxidants in an organism's protection against the oxidative stress, triggered by the ROS and reactive nitrogen compounds excess. Also it is an important component of antioxidant enzymes such as glutathione peroxidase, thioredoxin reductase and iodothyronine diodinases [22, 30].

Therefore, taking into account the results of the first step of the study and the information provided, the standard comprehensive treatment, that was prescribed for all patients with different LC severity degrees, was modified 
by the inclusion of the antioxidant medicine containing retinol palmitate (vitamin A) $100000 \mathrm{MO}$ and $\alpha$-tocopherol acetate (vitamin E) $0.1 \mathrm{~g}$ - 1 capsule per os once a day after meals daily, ascorbic acid $0.05 \mathrm{~g}-2$ tablets per os once a day after meals daily, selenium 0,0002 - 1 tablet per os once a day after meals daily within two months only for 66 patients with reduced RHI.

The results of the second step of the study, devoted to the determination of RHI after a course of complex differentiated treatment of the same patients with different LC severity severity, are shown in tables 2-4.

Table 2

Redox homeostasis index in patients with liver cirrhosis of different severity degree after the treatment with an index of less than 7.6 before the treatment ( $n ; \%$; Me $(25.0 \% ; 75.0 \%) ; p)$

\begin{tabular}{|c|c|c|c|c|c|c|c|}
\hline \multirow{3}{*}{\multicolumn{2}{|c|}{$\begin{array}{l}\text { LC severity classes } \\
\text { according to the } \\
\text { criteria of } \\
\text { C. H. Child - } \\
\text { R. N. Pugh }\end{array}$}} & \multicolumn{6}{|c|}{ RHI } \\
\hline & & \multicolumn{2}{|c|}{$<7.6$} & \multicolumn{2}{|c|}{ 7.6-18.1 } & \multicolumn{2}{|c|}{$>18.1$} \\
\hline & & $n$ & $\%$ & $n$ & $\%$ & $n$ & $\%$ \\
\hline \multicolumn{2}{|l|}{$\mathrm{A} ; n=11$} & 10 & 90.9 & 1 & 9.1 & 0 & 0,0 \\
\hline \multicolumn{2}{|c|}{$\operatorname{Me}(25.0 \% ; 75.0 \%)$} & \multicolumn{2}{|c|}{$4.6(2.9 ; 6.4)$} & \multicolumn{2}{|c|}{9.9} & \multicolumn{2}{|c|}{-} \\
\hline \multicolumn{2}{|l|}{$\mathrm{B} ; n=28$} & 16 & 57.1 & 12 & 42.9 & 0 & 0,0 \\
\hline \multicolumn{2}{|c|}{$\operatorname{Me}(25.0 \% ; 75.0 \%)$} & \multicolumn{2}{|c|}{$4.6(3.5 ; 6.4)$} & \multicolumn{2}{|c|}{$\begin{array}{c}10.2 \\
(9.3 ; 11.8)\end{array}$} & \multicolumn{2}{|c|}{ - } \\
\hline \multicolumn{2}{|l|}{$\mathrm{C} ; n=27$} & 26 & 96.3 & 1 & 3.7 & 0 & 0,0 \\
\hline \multicolumn{2}{|c|}{$\operatorname{Me}(25.0 \% ; 75.0 \%)$} & \multicolumn{2}{|c|}{$2.2(1.7 ; 3.7)$} & \multicolumn{2}{|c|}{9.7} & & \\
\hline \multicolumn{2}{|l|}{ Total $(n=66)$} & 52 & 78.8 & 14 & 21.2 & 0 & 0,0 \\
\hline \multicolumn{2}{|c|}{$\operatorname{Me}(25.0 \% ; 75.0 \%)$} & \multicolumn{2}{|c|}{$3.4(2.1 ; 5.6)$} & \multicolumn{2}{|c|}{$\begin{array}{c}9.9(9.4 \\
11.0)\end{array}$} & \multicolumn{2}{|c|}{ - } \\
\hline \multirow{3}{*}{$\begin{array}{l}\text { Significance } \\
(\%), p\end{array}$} & AvsB & \multicolumn{2}{|c|}{0.03} & \multicolumn{2}{|c|}{$>0.05$} & \multicolumn{2}{|c|}{ - } \\
\hline & BvsC & \multicolumn{2}{|c|}{0.004} & \multicolumn{2}{|c|}{$>0.05$} & \multicolumn{2}{|c|}{-} \\
\hline & AvsC & \multicolumn{2}{|c|}{$>0.05$} & \multicolumn{2}{|c|}{-} & \multicolumn{2}{|c|}{ - } \\
\hline \multirow{3}{*}{$\begin{array}{l}\text { Significance } \\
(\mathrm{Me}(25.0 \% \text {; } \\
75.0 \%), p\end{array}$} & AvsB & \multicolumn{2}{|c|}{$>0.05$} & \multicolumn{2}{|c|}{ - } & & \\
\hline & BvsC & & & & & & \\
\hline & AvsC & & & & & & \\
\hline
\end{tabular}

It was found that RHI less than the reference values after treatment was found in 52 cirrhotic patients, being 3.4 (2.1; 5.6), and taking into account the severity criteria according to C. G. Child - R. N. Pugh, - in ten (90.9\%) patients of class A $(4.6(2.9 ; 6.4))$, in $16(57.1 \%)$ patients of class B (4.6 ( $3.5 ; 6.4))$, in $26(96.3 \%)$ patients of class C (2.2 (1.7;
3.7)), with the significant difference between the frequencies in classes $\mathrm{A}$ and $\mathrm{B}(p=0.03), \mathrm{B}$ and $\mathrm{C}(p=0.004)$, as well as between the percentile values in classes $\mathrm{A}$ and $\mathrm{C}, \mathrm{B}$ and $\mathrm{C}(p=0.03 ; p=0.002)$, meaning that the frequency of cases of RHI less than the reference values is the largest, and its absolute value is the smallest in the patients of class $\mathrm{C}$.

In the patients with reduced RHI pre-treatment value, this index after treatment was found within the reference values in 14 patients being $9.9(9.4 ; 11.0)$. Based on the severity criteria according to C. G. Child - R. N. Pugh, this parameter was seen in one $(9.1 \%)$ patient of class A $(9.9)$, in $12(42.9 \%)$ patients of class $\mathrm{B}(10.2(9.3 ; 11.8))$, and in one $(3.7 \%)$ patient of class $\mathrm{C}(9.9)$, so RHI mostly has been returning to the reference values in patients of class $B$, and rarely - in patients of class $C$.

In the cirrhotic patients with a reduced RHI pre-treatment value, this parameter after the treatment did not exceed the reference values in any patient.

Table 3

Redox homeostasis index in patients with liver cirrhosis of different severity degree after the treatment with an index of 7.6-18.1 before the treatment $(n ; \%$; Me $(25.0 \% ; 75.0 \%) ; p)$

\begin{tabular}{|c|c|c|c|c|c|c|c|}
\hline \multirow{3}{*}{\multicolumn{2}{|c|}{$\begin{array}{l}\text { LC severity classes } \\
\text { according to the } \\
\text { criteria of } \\
\text { C. H. Child - } \\
\text { R. N. Pugh }\end{array}$}} & \multicolumn{6}{|c|}{ RHI } \\
\hline & & \multicolumn{2}{|c|}{$<7.6$} & \multicolumn{2}{|c|}{$7.6-18.1$} & \multicolumn{2}{|c|}{$>18.1$} \\
\hline & & $N$ & $\%$ & $n$ & $\%$ & $n$ & $\%$ \\
\hline \multicolumn{2}{|l|}{$\mathrm{A} ; n=3$} & 0 & 0.0 & 1 & 33.3 & 2 & 66.7 \\
\hline \multicolumn{2}{|c|}{$\operatorname{Me}(25.0 \% ; 75.0 \%)$} & \multicolumn{2}{|c|}{-} & \multicolumn{2}{|c|}{14.6} & \multicolumn{2}{|c|}{$23.4(21.9 ; 24.9)$} \\
\hline \multicolumn{2}{|l|}{$\mathrm{B} ; n=1$} & 0 & 0.0 & 0 & 0.0 & 1 & 100.0 \\
\hline \multicolumn{2}{|c|}{$\operatorname{Me}(25.0 \% ; 75.0 \%)$} & \multicolumn{2}{|c|}{ - } & \multicolumn{2}{|c|}{-} & \multicolumn{2}{|c|}{30.3} \\
\hline \multicolumn{2}{|l|}{$C ; n=0$} & 0 & 0.0 & 0 & 0.0 & 0 & 0.0 \\
\hline \multicolumn{2}{|c|}{$\operatorname{Me}(25.0 \% ; 75.0 \%)$} & \multicolumn{2}{|c|}{ - } & \multicolumn{2}{|c|}{ - } & \multicolumn{2}{|c|}{-} \\
\hline \multicolumn{2}{|l|}{ Total $(n=4)$} & 0 & 0.0 & 1 & 25.0 & 3 & 75.0 \\
\hline \multicolumn{2}{|c|}{$\operatorname{Me}(25.0 \% ; 75.0 \%)$} & \multicolumn{2}{|c|}{ - } & \multicolumn{2}{|c|}{14.6} & \multicolumn{2}{|c|}{$26.4(23.4 ; 28.3)$} \\
\hline \multirow{3}{*}{$\begin{array}{l}\text { Significance } \\
(\%), p\end{array}$} & AvsB & \multicolumn{2}{|c|}{-} & \multicolumn{2}{|c|}{-} & \multicolumn{2}{|c|}{$>0.05$} \\
\hline & BvsC & \multicolumn{2}{|c|}{-} & \multicolumn{2}{|c|}{-} & \multicolumn{2}{|c|}{-} \\
\hline & AvsC & \multicolumn{2}{|c|}{-} & \multicolumn{2}{|c|}{ - } & \multicolumn{2}{|c|}{-} \\
\hline \multirow{3}{*}{$\begin{array}{l}\text { Significance } \\
\text { (Me }(25.0 \% \text {; } \\
75.0 \%), p\end{array}$} & AvsB & \multicolumn{2}{|c|}{-} & & & & \\
\hline & BvsC & & & & & & \\
\hline & AvsC & & & & & & \\
\hline
\end{tabular}


It was found that out of four patients with RHI within the reference values before the treatment, its reduction after treatment was not detected in any patient.

RHI within the reference values was found in one person of class A, taking into account the severity criteria according to C. G. Child - R. N. Pugh with the value of 14.6.

RHI more than the reference values after treatment was in three patients, being $26.4(23.4 ; 28.3)$, and taking into account the severity criteria according to C. G. Child - R. N. Pugh, - in two patients of class A (23.4 (21.9; 24.9)) and one patient from class B (30.3).

Table 4

Redox homeostasis index in patients with liver cirrhosis of different severity degree after the treatment with an index of more than 18.1 before the treatment $(n ; \% ;$ Me $(25.0 \% ; 75.0 \%) ; p)$

\begin{tabular}{|c|c|c|c|c|c|c|c|}
\hline \multirow{3}{*}{\multicolumn{2}{|c|}{$\begin{array}{l}\text { LC severity classes } \\
\text { according to the } \\
\text { criteria of } \\
\text { C. H. Child - } \\
\text { R. N. Pugh }\end{array}$}} & \multicolumn{6}{|c|}{ RHI } \\
\hline & & \multicolumn{2}{|c|}{$<7.6$} & \multicolumn{2}{|c|}{$7.6-18.1$} & \multicolumn{2}{|c|}{$>18.1$} \\
\hline & & $\mathrm{n}$ & $\%$ & $\mathrm{n}$ & $\%$ & $\mathrm{n}$ & $\%$ \\
\hline \multicolumn{2}{|l|}{$\mathrm{A} ; n=5$} & 0 & 0.0 & 0 & 0.0 & 5 & 100.0 \\
\hline \multicolumn{2}{|c|}{$\operatorname{Me}(25.0 \% ; 75.0 \%)$} & \multicolumn{2}{|c|}{-} & \multicolumn{2}{|c|}{ - } & \multicolumn{2}{|c|}{$39.1(38.8 ; 42.3)$} \\
\hline \multicolumn{2}{|l|}{$\mathrm{B} ; n=0$} & 0 & 0.0 & 0 & 0.0 & 0 & 0.0 \\
\hline \multicolumn{2}{|c|}{$\operatorname{Me}(25.0 \% ; 75.0 \%)$} & \multicolumn{2}{|c|}{ - } & \multicolumn{2}{|c|}{-} & \multicolumn{2}{|c|}{ - } \\
\hline \multicolumn{2}{|l|}{$C ; n=0$} & 0 & 0.0 & 0 & 0.0 & 0 & 0.0 \\
\hline \multicolumn{2}{|c|}{$\operatorname{Me}(25.0 \% ; 75.0 \%)$} & \multicolumn{2}{|c|}{ - } & \multicolumn{2}{|c|}{ - } & \multicolumn{2}{|c|}{ - } \\
\hline \multicolumn{2}{|l|}{ Total $(n=5)$} & 0 & 0.0 & 0 & 0.0 & 5 & 100.0 \\
\hline \multicolumn{2}{|c|}{$\operatorname{Me}(25.0 \% ; 75.0 \%)$} & \multicolumn{2}{|c|}{-} & \multicolumn{2}{|c|}{0.0} & \multicolumn{2}{|c|}{$39.1(38.8 ; 42.3$} \\
\hline \multirow{3}{*}{$\begin{array}{l}\text { Significance } \\
(\%), p\end{array}$} & AvsB & \multicolumn{2}{|c|}{-} & \multicolumn{2}{|c|}{ - } & \multicolumn{2}{|c|}{ - } \\
\hline & $\mid \mathrm{BvsC}$ & \multicolumn{2}{|c|}{-} & \multicolumn{2}{|c|}{ - } & \multicolumn{2}{|c|}{$\begin{array}{ll}- \\
-\end{array}$} \\
\hline & AvsC & \multicolumn{2}{|c|}{-} & \multicolumn{2}{|c|}{-} & \multicolumn{2}{|c|}{-} \\
\hline \multirow{3}{*}{$\begin{array}{l}\text { Significance } \\
(\mathrm{Me}(25.0 \% \text {; } \\
75.0 \%), p\end{array}$} & AvsB & \multicolumn{2}{|c|}{-} & & & & 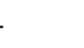 \\
\hline & BvsC & & & & & & - \\
\hline & AvsC & & & & & & - \\
\hline
\end{tabular}

In all five patients belonging to class $\mathrm{A}$, based on the severity criteria of C. G. Child - R. N. Pugh RHI was $39.1(38.8 ; 42.3)$, indicating that the antioxidant protection system was overactive in this category of patients.

The results obtained indicate that the complex differentiated treatment, estimated by the RHI, has an effect on redox homeostasis, which differs depending on the values of the RHI before the treatment and LC severity.

According to the results of the third step of the study, dedicated to the comparison of RHI values after the course of complex differentiated treatment of the patients with different LC severity degrees and the obtained RHI values before the treatment, it was found that the number of patients with $\mathrm{RHI}<7.6$ after treatment became reliably (by $18.7 \% ; p=0.01$ ) less (from 66 patients before the treatment to 52 patients after the treatment), and its absolute value was significantly greater as in total $(1.4(0.7 ; 3.5) ; 3.4(2.1 ; 5.6) ; p$ $<0.001$ ), as taking into account the LC severity criteria of C. G. Child - R. N. Pugh - in patients of class A (3.3 (1.7; 3.9); $4.6(2.9 ; 6.4) ; p=0.03)$, B (1.8 (0.8; $3.9) ; 4.6(3.5 ; 6.4) ; p=0.0005))$ and $\mathrm{C}(0.8(0.5 ; 1.5)$; $2.2(1.7 ; 3.7) ; p<0.001))$.

RHI being $9.9(9.4 ; 11.0)$ showed the normalization of redox homeostasis after the differentiated complex treatment in 14 patients from this group.

The results obtained indicate the feasibility of prescribing the antioxidants as a part of standard complex treatment, the efficacy of which is confirmed by the RHI positive dynamics.

Assessing the dynamics of RHI in four cirrhotic patients with its pre-treatment values within 7.618.1 , we found that after the treatment the decreased RHI was not detected in any patient, within the normal ranges - in one patient of class A (14.6), and more than the reference values - in three (two patients of class A and one patient of class B, taking into account the severity criteria according to C. G. Child - R. N. Pugh), being 26.4 (23.4; 28.3).

Estimating the dynamics of RHI more than 18.1 before the treatment, in all five patients who were in class A, according to the severity criteria of C. H. Child - R. N. Pugh, we found that RHI after the treatment significantly increased $(22.4(22.1 ; 24.0) ; 39.1$ (38.8; $42.3) ; p=0.02$ ), indicating the permanent hyperactivity of the antioxidant protection system in this category of patients.

Conclusions. The redox homeostasis index is an important criterion for assessment of the state of redox homeostasis in patients with cirrhosis of varying severity, which has established that the overwhelming (94.7 $\%$ ) of them are disorders of redox homeostasis, among which the patients with signs of prooxidants system prevalence and antioxidant system weakening are dominant $(88.0 \%)$, and the incidence of which significantly increases, as well as the value of the redox homeostasis index decreases with the liver cirrhosis severity increase; the redox homeostasis index allows to determine the feasibility of including the antioxidants in their comprehensive treatment, as well as to determine its effectiveness, which depends on its indicators for the treatment and severity of liver cirrhosis and is the lowest in patients at the stage of decompensation of the disease. 


\section{References}

1. Абрагамович MO, Абрагамович ОО. Класифікація цирозу печінки: ретроспективний погляд на проблему та сучасне їі вирішення з урахуванням синтропічних ко- та поліморбідних уражень хворого. Медицина транспорту України. 2013;2:10-16 (Abrahamovych MO, Abrahamovych OO. Classification of liver cirrhosis: retrospective view on a problem and its modern solution taking into account the syntropic co- and polymorbid lesions of the patient. Med Transport Ukr. 2013;2:10-16) (Ukrainian).

2. Абрагамович МО, Абрагамович ОО, Фаюра ОП, Толопко СЯ, Ферко МР. Уміст деяких ендотелійзалежних вазоактивних субстанцій у крові хворих залежно від тяжкості цирозу печінки та стану редокс-системи організму. Львівський клінічний вісник. 2019;4(28): 18-27 (Abrahamovych MO, Abrahamovych OO, Fayura OP, Tolopko SYa, Ferko MR. Content of Some Endothotelium-Dependent Vasoactive Substances in the Blood of Patients, Depending on the Liver Cirrhosis Severity and the Organism's Redox System State. Lviv Clinical Bulletin. 2019;4(28):19-27) (Ukrainian) https://doi.org/10.25040/lkv2019.04.014

3. Королюк МА, Иванова ЛИ, Майорова ИГ, Токарев ВЕ. Метод определения активности каталазы. Лабораторное дело. 1983;10:16-18 (Korolyuk MA, Ivanova LI, Mayorova IH, Tokarev VE. A method for determining the catalase activity. Laboratory Business. 1983;10:16-18) (Russian).

4. Тимирбулатов РP, Селезнев ЕИ. Метод повышения интенсивности свободнорадикального окисления липидосодержащих компонентов крови и его диагностическое значение. Лабораторное дело. 1981;4:209-211 (Timirbulatov RR, Seleznev EI. A method of increasing the intensity of free radical oxidation of lipid-containing blood components and its diagnostic value. Laboratory Business. 1981;4:209-211) (Russian).

5. Abdelazim SA, Darwish HA, Ali SA, Rizk MZ, Kadry MO. Potential antifibrotic and angiostatic impact of idebenone, carnosine and vitamin E in nano-sized titanium dioxide-induced liver injury. Cell Physiol Biochem. 2015;35:2402-2411. https://doi.org/10.1159/000374041

6. Abrahamovych O, Abrahamovych M, Tolopko S, Fayura O, Ferko M. Character and Frequency of the Variations of Coand Polymorbid Syntropic Extrahepatic Lesions and Their Dependence on the Hepatopulmonary Syndrome Severity Degree in Cirrhotic Patients. Georgian Medical News. 2016;11(260):34-41.

7. Abrahamovych OO, Abrahamovych MO, Dovhan YP, Ferko MR, Tolopko SYa, Fayura OP. Ultrasound Doppler-flowmetric signes of portal hypertension in patients with liver cirrhosis, complicated with edematous-ascitic syndrome. Gastroenterologia Polska. 2013;20(4):139-142.

8. Adikwu E, Deo O. Hepatoprotective effect of vitamin C (ascorbic acid). Pharmacol Pharm. 2013;4:84-92. https://doi. org/10.4236/pp.2013.41012

9. Abudu N, Miller JJ, Attaelmannan M, Levinson SS. Vitamins in human arteriosclerosis with emphasis on vitamin C and vitamin E. Clin Chim Acta. 2004;339:11-25. https://doi.org/10.1016/j.cccn.2003.09.018

10. Bhogade RB, Suryakar AN, Joshi NG. Effect of vitamin E supplementation on oxidative stress in hemodialysis patients. Indian J Clin Biochem. 2008;23:233-237. https://doi.org/10.1007/s12291-008-0052-0

11. Burk RF, Hill KE, Motley AK, Byrne DW, Norsworthy BK. Selenium deficiency occurs in some patients with moderate-to-severe cirrhosis and can be corrected by administration of selenate but not selenomethionine: a randomized controlled trial. Am J Clin Nutr. 2015;102:1126-1133. https://doi.org/10.3945/ajcn.115.110932

12. Burton GW, Ingold KU. Autooxidation of biological molecules. The antioxidant activity of vitamin $\mathrm{E}$ and related chain-breaking phenolic antioxidants in vitro. J Am Chem Soc. 1981;103:6472-6477. https://doi.org/10.1021/ja00411a035

13. Cankurtaran M, Kav T, Yavuz B, Shorbagi A, Halil M, Coskun T, Arslan S. Serum vitamin-E levels and its relation to clinical features in nonalcoholic fatty liver disease with elevated ALT levels. Acta Gastroenterol Belg. 2006;69:5-11.

14. Cichoż-Lach H, Michalak A. Oxidative stress as a crucial factor in liver diseases. World J Gastroenterol. 2014;20(25):80828091. https://doi.org/10.3748/wjg.v20.i25.8082

15. Deger Y, Yur F, Ertekin A, Mert N, Dede S, Mert H. Protective effect of alpha-tocopherol on oxidative stress in experimental pulmonary fibrosis in rats. Cell Biochem Funct. 2007;25(6):633-637. https://doi.org/10.1002/cbf.1362

16. Di Sario A, Candelaresi C, Omenetti A, Benedetti A. Vitamin E in chronic liver diseases and liver fibrosis. Vitam Horm. 2007;76:551-573. https://doi.org/10.1016/S0083-6729(07)76021-1

17. Harrison SA, Torgerson S, Hayashi P, Ward J, Schenker S. Vitamin E and vitamin C treatment improves fibrosis in patients with nonalcoholic steatohepatitis. Am J Gastroenterol. 2003;98:2485-2490. https://doi.org/10.1111/j.15720241.2003.08699.x

18. Hill DB, Devalaraja R, Joshi-Barve S, Barve S, McClain CJ. Antioxidants attenuate nuclear factor-kappa B activation and tumor necrosis factor-alpha production in alcoholic hepatitis patient monocytes and rat Kupffer cells, in vitro. Clin Biochem. 1999;32:563-570. https://doi.org/10.1016/S0009-9120(99)00056-9

19. Hosomi A, Arita M, Sato Y, Kiyose C, Ueda T, Igarashi O et al. Affinity for $\alpha$-tocopherol transfer protein as a determinant of the biological activities of vitamin E analogs. FEBS Lett. 1997;409:105-108. https://doi.org/10.1016/S00145793(97)00499-7

20. Houglum K, Venkataramani A, Lyche K, Chojkier M. A pilot study of the effects of d-alpha-tocopherol on hepatic stellate cell activation in chronic hepatitis C. Gastroenterology. 1997;113:1069-1073. https://doi.org/10.1053/gast.1997.v113. pm9322499

21. Kaur J, Shalini S, Bansal MP. Influence of vitamin E on alcohol-induced changes in antioxidant defenses in mice liver. Toxicol Mech Methods. 2010; 20:82-89. https://doi.org/10.3109/15376510903559950

22. Kryukov GV, Castellano S, Novoselov SV, Lobanov AV, Zehtab O, Guigo R. Characterization of mammalian selenoproteomes. Science. 2003;300:1439-1443. https://doi.org/10.1126/science.1083516

23. Mari M, Colell A, Morales A, VonMontfort C, Garcia-Ruiz C, Fernández-Checa JC. Redox control of liver function in health and disease. Antioxid Redox Signal. 2010;12:1295-1331. https://doi.org/10.1089/ars.2009.2634

24. Marí M, Morales A, Colell A, García-Ruiz C, Fernández-Checa JC. Mitochondrial glutathione, a key survival antioxidant. Antioxid Redox Signal. 2009;11:2685-2700. https://doi.org/10.1089/ars.2009.2695

25. Masalkar PD, Abhang SA. Oxidative stress and antioxidant status in patients with alcoholic liver disease. Clin Chim Acta. 2005;355:61-65. https://doi.org/10.1016/j.cccn.2004.12.012 
26. Padayatty SJ, Katz A, Wang Y, Eck P, Kwon O, Lee JH. Vitamin C as an antioxidant: evaluation of its role in disease prevention. J Am Coll Nutr. 2003;22:18-35. https://doi.org/10.1080/07315724.2003.10719272

27. Park JK, Ki MR, Lee HR, Hong IH, Ji AR, Ishigami A. Vitamin C deficiency attenuates liver fibrosis by way of up-regulated peroxisome proliferator-activated receptor- $\gamma$ expression in senescence marker protein 30 knockout mice. Hepatology. 2010;51:1766-1777. https://doi.org/10.1002/hep.23499

28. Sies H, Stahl W. Vitamins E and C, beta-carotene, and other carotenoids as antioxidants. Am J Clin Nutr. 1995;62:13151321. https://doi.org/10.1093/ajen/62.6.1315S

29. Singal AK, Jampana SC, Weinman SA. Antioxidants as therapeutic agents for liver disease. Liver Int. 2011;31(10):14321448. https://doi.org/10.1111/j.1478-3231.2011.02604.x

30. Tapiero H, Townsend DM, Tew KD. The antioxidant role of selenium and seleno-compounds. Biomed Pharm. 2003;57:134144. https://doi.org/10.1016/S0753-3322(03)00035-0

31. Tinggi U. Selenium: its role as antioxidant in human health. Environ Health Prev Med. 2008;13:102-108. https://doi. org/10.1007/s12199-007-0019-4

32. Weiskirchen R. Hepatoprotective and Anti-fibrotic Agents: It's Time to Take the Next Step. Front Pharmacol. $2016 ; 6: 303$. https://doi.org/10.3389/fphar.2015.00303

33. Yazar E, Konyalioglu S, Col R, Osman Birdane Y, Levent Bas A, Elmas M. Effects of vitamin E and prednisolone on some oxidative stress markers in endotoxemic rabbits. Revue Méd Vét, 2004;155(11):538-542.

34. Zhang M, Song G, Minuk GY. Effects of hepatic stimulator substance, herbal medicine, selenium/vitamin E, and ciprofloxacin on cirrhosis in the rat. 1996;110:1150-1155.

Стаття надійшла до редакції журналу 23.01.2020 р.

Conflict of interest

The authors of this article argue that there is no conflict of interest.

\title{
Індекс редокс-гомеостазу як критерій диференційованого включення антиоксидантів до комплексного лікування хворих на цироз печінки різного ступеня тяжкості та оцінки його ефективності
}

\author{
О. П. Фаюра, М. О. Абрагамович, О. О. Абрагамович, Л. Р. Фаюра
}

Вступ. Перебіг цирозу печінки (ЦП) характеризується появою і наростанням тяжкості синтропічних коморбідних уражень, спричинених порушенням редокс-гомеостазу з перевагою у системі прооксидантів, який і реалізує свій патогенетичний механізм через порушення ендотеліальної функції. Із огляду на важливу роль оксидативного стресу серед етіологічних і патогенетичних механізмів виникнення та перебігу недуги, у комплексному лікуванні хворих на ЦП фармакологічний вплив на нього $€$ пріоритетним і вимагає трактувати його як одну з головних «мішеней».

Мета. Охарактеризувати індекс редокс-гомеостазу (IPГ) як критерій диференційованого включення антиоксидантів до комплексного лікування хворих на цироз печінки різного ступеня тяжкості та оцінювання його ефективності.

Матеріали й методи. Дослідження проведено у три кроки. Після отримання письмової згоди на проведення обстеження до дослідження за рандомізованим принципом із попередньою стратифікацією за наявністю ЦП залучено 75 хворих (23 жінки (30,7 \%), 52 чоловіки (69,3\%), середній вік $-47,2 \pm 10,4$ років), які перебували на комплексному клінічно-лабораторно-інструментальному обстеженні та стаціонарному лікуванні у Львівському обласному гепатологічному центрі. Серед показників редокс-гомеостазу визначали вміст малонового діальдегіду (МДА) і каталази (КАТ), за результатами співвідношення яких запропоновано визначати IРГ. Зменшене значення IPГ $(<7,6)$ - показник порушення редокс-гомеостазу з перевагою у системі прооксидантів, значення в межах 7,6-18,1 - баланс у системі редокс-гомеостазу, збільшене $(>18,1)$ - показник надмірної активності антиоксидантної системи.

Перший крок дослідження присвячений визначенню IРГ для виявлення порушень редокс-гомеостазу у хворих на ЦП різного ступеня тяжкості до початку курації, тобто отриманню інформації про наявність хворих зі зменшеними, нормальними та збільшеними його значеннями, що дозволяє рекомендувати модифікацію стандартного комплексного лікування призначенням антиоксидантів (лікарський засіб, який містить ретинолу пальмітату (вітаміну А) 100000 МО та $\alpha$-токоферолу ацетату (вітаміну Е) 0,1 г - по 1 капсулі 1 раз на день, внутрішньо після їди щодня, аскорбінову кислоту 0,05 г - по 2 табл. раз на день, внутрішньо після їди щодня, селен 0,0002 г- по 1 табл. 1 раз на день, внутрішньо після їди щодня упродовж двох місяців) тільки хворим 
зі зменшеним ІРГ. Другий крок дослідження присвячений визначенню ІРГ після курсу комплексного диференційованого лікування цих же хворих на ЦП різного ступеня тяжкості. Третій крок дослідження передбачав порівняння показників ІРГ, отриманих після проведеного курсу комплексного диференційованого лікування хворих на ЦП різного ступеня тяжкості, з показниками у них ІРГ до початку лікування.

Фактичний матеріал опрацьовано на персональному комп’ютері у програмах Excel 2010, Statistica 6.0, RStudio v. 1.1.442 та R Commander v. 2.4-4. Отримані результати у випадку нормального розподілу представлені У вигляді Ме [25,0 \%; 75,0 \%]. Статистично достовірною вважали різницю, якщо $p<0,05$.

Результати. У більшості хворих на ЦП (71 особа, що становить 94,7 \% усіх, залучених у дослідження) $\epsilon$ порушення редокс-гомеостазу, серед яких домінують хворі (66 осіб, що становить 88,0 \% усіх, залучених у дослідження) із ознаками переважання у системі прооксидантів та послаблення активності антиоксидантної системи, частота випадків яких достовірно збільшується, а значення ІРГ зменшується з наростанням тяжкості ЦП. Оскільки порушення редокс-гомеостазу з ознаками послаблення активності антиоксидантної системи діагностовані у більшості хворих на ЦП, а вони визначають великою мірою особливості перебігу недуги та появу і наростання тяжкості синтропічних коморбідних уражень, потрібне його медикаментозне коригування. Індекс редокс-гомеостазу дозволяє визначити доцільність включення антиоксидантів до комплексного лікування, а також з'ясувати його ефективність, яка залежить від його показників до лікування і тяжкості цирозу печінки та $є$ найменшою у хворих на стадії декомпенсації недуги. Виявлено, що після проведення комплексного, модифікованого нами диференційованого стандартного лікування з використанням антиоксидантів IPГ збільшується у хворих із первинним його зменшенням, результатом чого стає поліпшення стану редокссистеми, що найбільше виражено у хворих класу В, а найменше - класу С за критеріями Ч. Г. Чайлд Р. Н. П'ю.

Висновки. Індекс редокс-гомеостазу є важливим критерієм оцінювання стану редокс-гомеостазу у хворих на цироз печінки різного ступеня тяжкості, дає змогу визначити доцільність включення антиоксидантів до комплексного лікування, а також з'ясувати його ефективність, що є найменшою у хворих на стадії декомпенсації недуги.

Ключові слова: цироз печінки, оксидативний стрес, антиоксиданти, редокс-гомеостаз, вітаміни.

\title{
Redox Homeostasis Index as a Criterion for Differentiated Inclusion of Antioxidants in Complex Treatment of the Patients with Liver Cirrhosis of Different Severity Degrees and Evaluation of Its Effectiveness
}

\author{
O. Fayura, M. Abrahamovych, O. Abrahamovych, L. Fayura
}

Introduction. The course of liver cirrhosis (LC) is determined by the appearance and increase of the severity of syntropic comorbid lesions caused by the redox homeostasis disorders with the prooxidants system activity predominance and realization of its pathogenetic mechanism through the endothelial dysfunction. Due to the important role of oxidative stress among the etiologic and pathogenetic mechanisms of the LC onset and course, the pharmacological impact on it in the complex treatment deserves priority, being one of the main "targets".

The aim of the study. To characterize the redox homeostasis index (RHI) as a criterion for the differentiated inclusion of antioxidants in the complex treatment of the patients with liver cirrhosis of different severity degree and evaluation of its effectiveness.

Materials and methods. The study was conducted in three steps. After obtaining the written consent to conduct the survey, 75 patients (23 women $(30.7 \%), 52$ men $(69.3 \%)$, mean age $-47.2 \pm 10.4$ years) were enrolled in a randomized trial with preliminary stratification by the presence of LC. All of them underwent the complex clinicallaboratory-instrumental examination and inpatient treatment at Lviv Regional Hepatology Center. The state of redox homeostasis was evaluated by the malondialdehyde (MDA) and catalase (CAT) levels determining, and, on the basis of the received results, we proposed to calculate RHI. Reduced RHI $(<7.6)$ was considered an indicator of redox homeostasis abnormality with a predominance in the prooxidant system, a value within 7.6-18.1 - a balance in the redox homeostasis system, increased (>18.1) - an indicator of the antioxidant system excessive activity.

The first step of our study was to determine the RHI to detect the disorders of redox homeostasis in patients with different severity degrees before the treatment, i.e. obtaining the information about the presence of patients with reduced, normal and increased values, which allows us to recommend the modification of standard complex treatment 
using antioxidants (medicine containing retinol palmitate (vitamin A) $100000 \mathrm{MO}$ and $\alpha$-tocopherol acetate (vitamin E) $0.1 \mathrm{~g}-1$ capsule per os once a day after meals daily, ascorbic acid $0.05 \mathrm{~g}-2$ tablets per os once a day after meals daily, selenium $0,0002 \mathrm{~g}-1$ tablet per os once a day after meals daily for two months) only for patients with reduced RHI. The second step of the study was devoted to the determination of RHI after a course of complex differentiated treatment of the same patients with LC of varying severity. The third step of the study was to compare the RHI obtained after the course of complex differentiated treatment of patients with LC varying severity degrees with the values of the RHI prior to treatment. The actual material was processed on a personal computer in Excel 2010, Statistica 6.0, RStudio v. 1.1.442 and R Commander v. 2.4-4. The results obtained were presented as Me [25.0 \%; $75.0 \%]$. The difference was considered statistically significant if $p<0.05$.

Results. The overwhelming majority of patients with LC (71 persons, representing $94.7 \%$ of all those involved in the study) have disorders of redox homeostasis, among which patients with the signs of the prooxidant system prevalence and the antioxidant system activity attenuation are predominant ( 66 persons, accounting for $88.0 \%$ of all those involved in the study), and the incidence of them significantly increases, as well as the value of RHI decreases with LC decompensation. Since redox homeostasis disorders with the signs of attenuation of the antioxidant system activity have been diagnosed in the vast majority of patients with LC, and they determine to a large extent the features of the disease as well as the onset and severity increase of syntropic comorbid lesions, its medication adjustment is needed. RHI allows to determine the feasibility of including the antioxidants in their comprehensive treatment, as well as to determine its effectiveness, which depends on its indicators for the treatment and severity of liver cirrhosis and is the lowest in patients at the stage of decompensation of the disease. It is revealed that after the administering of the complex, differentiated standard treatment, modified by us, with the use of antioxidants RHI increases in patients with its primary decrease, which results in an improvement of the redox system state, which is the most pronounced in patients of class B, and the least - of class C by the criteria of C. G. Child R. N. Pugh.

Conclusions. The redox homeostasis index is an important criterion for assessment of the state of redox homeostasis in patients with liver cirrhosis of different severity, that allows to determine the feasibility of including the antioxidants in their complex treatment, as well as to determine its effectiveness, which is the lowest in patients with decompensated liver cirrhosis.

Keywords: liver cirrhosis, oxidative stress, antioxidants, redox homeostasis, vitamins.

\section{Information about the authors}

1. Fayura Oksana Petrivna; Danylo Halytsky Lviv National Medical University, Department of Internal Medicine N 1 (69 Pekarska Street, Lviv, 79010; +38 (032) 236-84-19); Master of Medicine, Assistant Professor; 79067, 7 Poludneva Street, Lviv, 79067; + 3809681417 49, +38 (032) 271-27-65); fayurchuk@ukr.net; https://orcid.org/0000-0003-11229030

2. Abrahamovych Orest Ostapovych; Danylo Halytsky Lviv National Medical University, Department of Internal Medicine N 1 (69 Pekarska Street, Lviv, 79010; +38 (032) 276-97-63); Doctor of Medical Sciences, Professor, Head of the Department; 8 Lytovska Street, Lviv, 79034; + 38050665 29 95, +38 (032) 270-44-20); docorest@gmail.com; http:// orcid.org/0000-0001-6862-6809

3. Abrahamovych Maryana Orestivna; Danylo Halytsky Lviv National Medical University, Department of Family Medicine (69 Pekarska Street, Lviv, 79010; +38 (032) 236-84-19); Doctor of Medical Sciences, Professor; 8 Lytovska Street, Lviv, 79034; +38 050500 74 77, +38 (032) 270-44-20); marjana2003@ukr.net; https://orcid.org/0000-0002-2827-7170

4. Fayura Lyubov Romanivna; Institute of Cell Biology of the National Academy of Sciences of Ukraine, Department of Molecular Genetics and Biotechnology (14/16 Drahomanova Street, Lviv, 79005; +38 (032) 261-21-08); PhD, Senior Researcher; 7 Poludneva Street, Lviv, 79067; + 3809657999 14, +38 (032) 271-27-65); fayural@gmail.com; https:// orcid.org/0000-0001-7129-1122 